Original Article

\title{
Discovery of hearing impairment by the family: seeing an idealized future collapse*
}

\author{
Descoberta da deficiência auditiva pela família: vendo o futuro idealizado desmoronar \\ Descubrimiento de la discapacidad auditiva por la família: contemplando el colapso del futuro idealizado
}

\author{
Sheila de Souza Vieira ${ }^{1}$, Maria Cecília Bevilacqua ${ }^{2}$, Noeli Marchioro Liston \\ Andrade Ferreira ${ }^{3}$, Giselle Dupas ${ }^{4}$
}

\begin{abstract}
Objective: To portray the family experience when the discovery of hearing impairment in their child. Methods: Qualitative research with Symbolic Interactionism and Grounded Theory as theoretical and methodological frameworks. Data collection instrument: semi-structured interview. The study included nine families (32 participants). Results: The theme, "Seeing an idealized future collapse", shows that for the family, discovered the possibility of having a child with hearing loss is a moment that involves many negative feelings. Conclusion: Discover the hearing loss has a meaning of the expected loss of the perfect child, frustrated expectations and uncertain future. The family has been inadequately approached and the diagnosis has been made late, which requires immediate changes to the practices of professionals.
\end{abstract}

Keywords: Family; Disabled children; Hearing loss; Life change events; Family nursing

\section{RESUMO}

Objetivo: Retratar a experiência familiar, quando da descoberta da deficiência auditiva de um filho. Métodos: Pesquisa qualitativa, tendo o Interacionismo Simbólico e a Teoria Fundamentada nos Dados, como referenciais teóricos e metodológicos. Instrumento de coleta de dados: entrevista semiestruturada. Participaram do estudo nove famílias (32 participantes). Resultados: O tema, "Ver desmoronar um futuro idealizado", evidencia que, para a família, a descoberta da possibilidade de ter uma criança com deficiência auditiva é um momento complexo que envolve inúmeros sentimentos negativos. Conclusão: Descobrir a deficiência auditiva tem um significado de perda da criança perfeita esperada, de expectativas frustradas e futuro incerto. A família tem sido abordada inadequadamente e o diagnóstico tem sido feito tardiamente, o que exige mudanças imediatas das práticas dos profissionais envolvidos.

Descritores: Família; Crianças com deficiência; Perda auditiva; Acontecimentos que mudam a vida; Enfermagem famíliar

\section{RESUMEN}

Objetivo: Retratar la experiencia familiar, cuando se descubre la deficiencia auditiva de un hijo. Métodos: Investigación cualitativa, teniendo al Interaccionismo Simbólico y la Teoría Fundamentada en los Datos, como referenciales teóricos y metodológicos. Instrumento de recolección de dados: entrevista semiestructurada. Participaron en el estudio nueve familias (32 participantes). Resultados: El tema, "Ver desmoronarse un futuro idealizado", evidencia que, para la familia, el descubrimiento de la posibilidad de tener un niño con deficiencia auditiva es un momento complejo que involucra innumerables sentimientos negativos. Conclusión: Descubrir la deficiencia auditiva tiene un significado de pérdida del niño perfecto esperado, de expectativas frustradas y futuro incierto. La familia ha sido abordada inadecuadamente y el diagnóstico realizado tardíamente, lo que exige cambios inmediatos de las prácticas de los profesionales involucrados.

Descriptores: Familia; Niños con discapacidad; Pérdida auditiva; Acontecimientos que cambian la vida; Enfermería de la familia

\footnotetext{
* Study extracted from the Master's dissertation entitled 'Mobilizando-se para resgatar a vida através do implante coclear: a experiência da familia da criança com deficiência auditiva - Post-Graduate Program in Nursing, Federal University of São Carlos - UFSCAR - São Carlos (SP), Brazil.

1 Master of Nursing from the Federal University of São Carlos - UFSCar - São Carlos (SP), Brazill.

${ }^{2}$ Doctor of Psychology of Education. Full Professor of Audiology, Department of Phonoaudiology at the Bauru School of Dentistry (FOB) of the University of São Paulo- USP Bauru (SP), Brazil.

${ }^{3}$ Doctor of Nursing. Federal University of São Carlos - UFSCar - São Carlos (SP), Brażil.

${ }^{4}$ Doctor of Nursing. Federal University of São Carlos - UFSCar - São Carlos (SP), Brażil.
} 


\section{INTRODUCTION}

The discovery of a chronic health condition in a member of the family is a complex moment - a situation that is more serious in childhood and one permeated with negative feelings and various behaviors, such as: rebellion, fear, frustration, non acceptance, fright, upset, despair, anguish, confusion, sadness, guilt, contrariness, prejudice, an empty feeling inside, shock, shame, depression and anxiety ${ }^{(1-5)}$. Thus the discovery of Hearing Impairment (HI) configures as the loss of a perfect child, violation of positive expectations, generating frustrations compared by some families with the experience of mourning ${ }^{(2-3)}$. In the presence of diseases, deficiencies and abnormalities, there is a change in the involvement of members, in the shared life and intrafamily relationships, causing substantial changes particularly in the beginning ${ }^{(6-10)}$. When the discovery of $\mathrm{HI}$ occurs in childhood, it is a challenging situation of great impact on the family, demanding great mobilization that involves adaptations and re-formulation of meanings that vary from one family to another.

From this aspect, parents may react in a similar manner when they receive this diagnosis, however, the expectations with regard to the child with $\mathrm{HI}$ differ. For some, the desire is that the child should speak; others accept sign language by recognizing that the child is unable to develop speech, and there are parent who accept sign language and speech (7).

The importance of language in the reception and structuring of information, in perceptual organization, in learning and in social relationships translates into an essential element in childhood development ${ }^{(11)}$, therefore the need for diagnosing $\mathrm{HI}$ as early as possible is justified ${ }^{(12-15)}$. On the other hand, late identification of the impairment may lead to disadvantages and academic, social and emotional difficulties ${ }^{(13)}$ as well as affecting the child's self-esteem. In this context, the time necessary for approaching its linguistic needs and prepare it for going to school is longer, clearly leaving the child at a disadvantage in comparison with children who can hear ${ }^{(16)}$.

The difficulties in communication with the child represent and imperative challenge in the initial stage and may generate nervousness in the parents, causing them to desist from communicating with the child, frustration, insecurity or persistence ${ }^{(1)}$. On the other hand, the loss/ absence of hearing may cause irritation, lack of interest, rebellion and bad behavior in the child ${ }^{(17)}$.

In view of the foregoing, this study had the following objective: to portray the family's experience when they discover their child has hearing impairment.

\section{METHODS}

A research with a qualitative approach, with Symbolic Interactionism (SI) ${ }^{(18)}$ and the Grounded Theory (GT) ${ }^{(19)}$, as theoretical and methodological reference, respectively. These references were used to understand the world of the experience lived through by the family of the child with HI, and apprehend the meanings it attributes to the innumerable situation with which family members are faced on a daily basis.

With regard to the physical aspects, the research project was evaluated and approved by the Research Ethics Committee of the craniofacial anomaly rehabilitation hospital "Hospital de Reabilitação de Anomalias Craniofaciais" of the University of São Paulo (HRAC/USP), Protocol No. 182/2009-SVAPEPE-CEP. Afterwards, having read and received explanation of the Term of Free and Informed Consent (in accordance with Federal Resolution No.196/96 of the National Health Council), this was signed by the members of each family.

For data collection, the semi-structured interview that had received consent was the instrument used.

The research subjects were the families of children with HI, Cochlear Implant users, selected from the list of patients made available by the Coordinators of the Implant Center. The following inclusion criteria were considered: have a child implanted at least 1 year ago, and enrolled in Primary School; be a patient at the Audiology Research Center ("Centro de Pesquisas Audiológicas-CPA") of HRAC/USP, at the Bauru campus (SP), and reside in the State of São Paulo. Nine families participated in the Study (Chart 1), with a total of 32 individuals. In order to assure anonymity, the families were identified numerically in the order in which the interviews were held, and each member was represented by the degree of relationship in relation to the implanted child (E.g.: Family 1: Father1, Mother1, Child1, Sibling1).

Chart 1. Characterization of the interviewed families of implanted children. São Carlos-SP, 2011

\begin{tabular}{|ll|}
\hline Family's Identification: Participating members & Child's Identification (gender, date of birth, etiology) \\
\hline Family 1: Mother, Child, Brother & Child 1 (male, 02/06/2001, Congenital Deafness) \\
Family 2: Father, Mother, Child & Child 2 (female, 11/09/2003, Genetic etiology) \\
Family 3: Father, Mother, Child & Child 3 (female, 13/11/2002, Congenital deafness) \\
Family 4: Father, Mother, Child & Child 4 (female, 15/09/2001, Pneumococcal Meningitis) \\
Family 5: Mother, Maternal Grandmother, Child & Child 5 (male,19/09/2002, Acquired Deafness) \\
Family 6: Father, Mother, Child & Child 6 (female, 15/09/1998, Unknown etiology) \\
Family 7: Father, Mother, Child, Sister & Child 7 (female, 23/04/2001, Maternal Rubella) \\
Family 8: Father, Mother, Child, Cousin, Uncle & Child 8 (female, 04/06/1999, Auditory Neuropathy Spectrum) \\
Family 9: Father, Mother, Brother, Aunt, Family Friend & Child 9 (female, 22/12/1998, Unknown etiology) \\
\hline
\end{tabular}


The interviews were held between September 2009 and October 2010, with an interview being held with each family at their home, since the proposal was to reunite the largest possible number of members, so that the data were more representative of the family group's experience. The number of families was not predetermined, seeing that by means of GT, theoretical sampling occurs because of the need for research and relevance of the theory that is being constructed ${ }^{(19)}$. The interviews were recorded and transcribed in full, and the data were collected and analyzed concomitantly, in accordance with the presuppositions of GT, by means of coding and categorization of the data, and understanding of the findings.

\section{RESULTS}

Data analysis allowed one to identify that for the family members, the discovery of a $\mathrm{HI}$ in their child means the loss of a perfect and expected child, having their dreams shattered, expectations frustrated and an uncertain future.

The experience of the family of the child with $\mathrm{HI}$ begins with the suspicion of something different in the child. As this grows, the family begins to note alterations in the daily interaction, absence of reaction to stimuli, particularly sounds, in comparison with previous experiences with older children or with the reactions expected at that age; the child is constantly tested, but without obtaining responses that give the family assurance that the perception is correct.

"I, as mother, thought that she was different, because she had difficulty in going to sleep, she was a very electric child, never slept in the afternoon. When she slept, the world could end and she would not wake up (Mother6). They did tests of clapping hands and she never reacted. I think the child born with an impairment is more sensitive, sees an image and turns at once! We thought she was turning because of the sound but that wasn't so. (Father6)."

Although they perceived something strange, the family frequently carries on not wanting to believe in their suspicions, mostly because they did not want to look for something they did not wish to find.

Thus, due to the difficulty in accepting that the child does not hear, in some cases, the family puts off having the requested exams performed for as long as possible, and delays in seeking help, because they have no conception of their suspicion being real.

"At first, one perceived it at home, but thought it was distraction, did not accept it, and time went by. And the reaction of a child was to scare us, not so?! That is why it took up to a year. We perceived right at the beginning that she did not respond to noises, but we always insisted that it was distraction. Even so I delayed making the appointment for the phono for a month, because we thought it was not so (Mother3)."
The experience of having a deaf child in the family may appear during gestation, when the mother is affected by an infection, the is informed of the possibility of fetal compromise.

"In the beginning it was very painful. Due to the fact that I had rubella at 2 to 3 months of pregnancy, it was a great expectation. Everyone was worried because of the fact that the child might be born deaf, blind. At the time she was born, we lived at his parents' bouse, so everything was paying attention at the time when babbling would develop to see if she would do so. (Mother7)."

When the possibility of a deficiency in the child arises in the pre-natal period, it may feasible to prepare the family for the situation; however, the anticipated suffering occurs by reason of the expectation extended up to the birth with the finding of deafness.

"One is sad, because one nurses the expectation that if God is willing, everything will turn out right, nothing will come of it, but at the same time, we were prepared. When it was found... (Father7) it seemed as though we already knew $50 \%$ of the result (...) we knew that she wasn't like any other child (Mother7)."

Even when putting off seeking help, the family continues to feel uneasy inside, which makes them start the process of mobilization, investigating their concerns. Although some families put off seeking explanations, others promptly seek help in search of information. The delay in confirming the diagnosis may occur due to the delay by professionals in diagnosing and investigating the problem.

"Then I started chasing after the exam, called in on the pediatrician, he did tests, said that there was nothing wrong with her (...), various pediatricians said (...). At the time I didn't have medical insurance, we delayed in having the BERA exam performed. We chased after the Municipality and as this appliance was always broken, time went passing by. So, when we went to have it done, it was when we took out medical insurance and she was already 1 year old (Mother6)."

"At 7 months, I started complaining to the pediatrician that I thought she was strange. "There is nothing wrong... beautiful, bealtby child, what do you want?'. Afterwards I went back and said that my suspicion was hearing, and the pediatrician Imagine?!". Every month I took her to the doctor for control, he did that test of snapping his fingers and she followed his finger. By now she was 1 year and 1 month old, I was complaining, and the doctor was saying it was nothing, that it was all in my head (Mother9)."

Children with acquired deafness resulting from infections start presenting signs and symptoms that the family perceives, and quickly go and seek medical attention. Late and/or inappropriate medical interventions contribute to the occurrence of sequelae, such as deafness.

"The story began like this, she played normally all day... at night, I thought it was strange because she asked to go to sleep earlier (...) when it was one o'clock in the morning, she starting being sick, vomiting. I wanted to take her to the doctor, and she said 'not now, dad', but the vomiting was strange... and I insisted with her. She had a bad turn again, and the 3rd time, she got up and bumped into 
the wardrobe and fell flat on her back (...) at this stage she had no coordination whatever and by now it was 4 h3 30 in the morning. I put her into the car and went to the emergency first aid center. When I arrived there, the doctor did not want to attend to her, told me to go back home and wait until early tomorrow and go to the health post, said it was a virus, and did not touch her (...) I called the police... Went to "Santa Casa"(hospital), and the doctor did not want to admit her, but no one touched her. By this time she was unconscious, since the emergency first aid center. Gave her an injection for fever, her temperature was 42 degrees, put her on a drip (...) six doctors passed, no one touched her. According to the nurse, they thought I was desperate, because I had dropped her on the floor, and because of this she was unconscious. When the neurologist arrived she said Father, your daughter has meningitis"... They isolated me, her, the room, because they were afraid, because it is a contagious disease and they had another nine children there. When the result came out, she went directly to the ICU, and the doctor said to me, better not speak, he disillusioned me... (Father4)."

"She came out of hospital and was not walking (...) we imagined that this would be the sequela. Because the doctor said, if she lived she would have sequelae, and was very clear about this. Days went by at him, and after 5 days, she telephoned her father, and did not hear what her father said (Mother4). Her mother spoke to me angrily 'what are you saying to the girl? that she started crying'(Father4). Because I talked to her and she understood, but not on the telephone (Mother4)."

Reports have shown that any family with a member who has a chronic health situation reacts in a similar manner, thus it is inevitable to go through the first stage of the impact: confirmation of the diagnosis. This period is permeated with a set of negative feelings and sensations such as rebellion, non acceptance, and fright, among others.

"When we discovered, it was a shock because we didn't expect it. It was very difficult and painful (Mother3). I did not accept my daughter in this condition, I didn't want her to have this, that didn't get through to me (...) it was the worst day of our lives (Father3)."

"When we discovered, it was that initial fright, that thing that we ourselves make o horrible prognosis, because we did not know the implant. My family felt very rebellious, did not accept (Mother2). In the beginning it was more difficult (...) I had no idea whatever, because no one in the family has a hearing problem. (...) It is something that makes you lose your footing; you are left not knowing what to do (Father2)."

When they feels without control of the situation in the face of news that changes the direction of their plans, the family members are anguished by fear of the unknown and see their shattered dreams collapsing. The main feeling triggered at this time is fear.

"We thought she would be one of these children who become marginalized, which ended up not being so. We were ignorant, and in some way, prejudiced as well. We thought that a deaf person was someone pitiful, and when we discovered that she was going to be deaf, we already had the image of someone pitiful (...) that was going to be marginalized (Father6)."
Fear is a feeling that permeates the entire experience of deafness, but it is of a variable nature and intensity; it arises at the time of the suspicion that something wrong is happening, with the confirmation of the diagnosis, and also during the course of the experience. Lack of knowledge about deafness, its repercussions, possibilities for treatment and support, make this phase extremely difficult. The situation makes the family suffer, generating a continuous anguish about what to expect from a child with speech, communication and sociabilization problems, amongst others. In addition, it triggers a certain anguish due to the constant "worry".

"The deficiency was discovered at 7 months, I cried a lot in the beginning because I was afraid she would not speak and understand things. I didn't think she would develop so much (Mother7). I already though in the long term, because one knows about prejudice which is... I thought about how her professional life would be, the difficulties (...) it was difficult! My despair was very great, when she was over 1 year old and she didn't speak (Father7)."

In addition to the suffering triggered by the discovery of HI, the family also suffers because of other aggravating factors, such as the way in which deafness is notified, the lack of information and guidance about this deficiency, and the therapeutic resources available. The suffering could be ameliorated if possible ways and words of encouragement and hope were presented.

"The otorbinologist, I thought him rather insensitive to say the very first time he spoke 'you are going to have to get used to life now that he is hearing impaired, everything is going to change'. But, we were not prepared, because he wasn't born like that (...) he didn't speak in such a way that we could understand look, your son is hearing impaired!' He said 'school, everything in his life is going to be different, in his case, the implant there is, is very expensive'... that we were not going to manage to get it (Mother5)."

"He kind of said 'you are poor, you are not going to be able to get it' (Grandmother5). He could have said 'there is Bauru, the implant is this...'. He didn't say anything! He said 'your son is hearing impaired and has to get used to it now. There is an association of deficient persons here' (Mother5)."

The manner in which diagnoses and prognoses of $\mathrm{HI}$ are transmitted, represents a violation of the family's rights, because in many situations it occurs in an inappropriate and harsh manner. Thus, the omission of information about the resources available for the treatment of deafness and the lack of referral to specialized centers wears the family out unnecessarily.

"On the day the doctor gave us the news, my God! He opened the result: 'She is deaf, her case is irreversible, she will not speak...', to our faces, short and to the point. He started giving us the address of Avape, and said that she would speak only by signs (mother9). We asked him 'doctor isn't there any operation?'. And he said 'There is nothing to do, she will have to live with this, put in a little appliance, she is deaf'. A professional guy in the 
area does not know that there is a cochlear implant, it's a joke, isn't it?! (Father9)."

For the family, receiving the confirmation of diagnosis in a cautious and adequate manner helps to minimize the stress of this moment and encourages the family to proceed.

"In Bauru, the doctor said that on that day there was nothing to do, no appliance, no implant, but 'since medicine is well advanced, maybe tomorrow or afterwards something appears that will solve her problem' (...) He said that there was an experiment being done with an implant for persons who had neuropathy (Mother8)."

"In Campo Grande, they already informed about Bauru. We were a little sad, but they encouraged us, because there was going to be a way, she was going have this implant (Father8)."

\section{DISCUSSION}

By virtue of the foregoing, it was possible to perceive that as with the discovery and confirmation of other chronic health conditions, families who experience a member with HI in childhood go through the initial process of suspicion of differences in the child when compared with others of the same age; denial and non acceptance of the evidences of the deviation from the expected pattern of child development; beginning of the process of mobilization in search of responses for their concerns and desires; and suffering when they receive the diagnosis. This initial stage is one of impact, permeated with negative feelings, particularly fear in the face of the unknown; in which the break-down occurs of plans, expectations and previous idealizations that they had for their child; and experiencing the aggravation of suffering by the inadequacy of the professionals involved in their approach to the family.

Therefore in prenatal and childcare follow-ups, and in the activities of popular health education, there should be in-depth instructions for parents about child growth and development to guide follow-up of the child by families. For this to occur, it is also imperative for professionals who follow up children to have technical and scientific knowledge about the normal parameters of auditory behavior ${ }^{(20)}$.

Nursing is included in this group of professionals, because they act in conjunction with these families in basic care in the Family Health Strategies, in maternity hospitals, in medium and high complexity services, when the care for women with high-risk pregnancies and in the episodes of child hospitalizations.

A study conducted at the Teaching Hospital of the School of Medicine in Ribeirão Preto, of the University of São Paulo (USP), in 2006, recommended that it was necessary to have a more in-depth approach to the development of hearing, evaluation, early diagnosis and treatment of deafness in the training of Medical students and Pediatric residents; and there must be greater cooperation among pediatricians, phonoaudiologists and otorhinolaryngolo- gists in divulging the procedures of auditory triage, because pediatricians are the parents' first source of information and reference ${ }^{(21)}$. This approach also needs to be included in the training of nurses and all professionals in the health area, who need to be made aware of the complexity of this moment and the impact it has on the family.

Thus, as has been presented in other studies ${ }^{(22)}$, some families rapidly suspect some abnormality in the child, leading them to seek professionals in order to investigate their concerns. However, many professionals do not give much credit to information given by the family, and take long to make the necessary diagnoses and referrals.

The impact felt at the time of diagnosis is inevitable, because the family feels out of control of the situation and is unable to project the planned future. Thus questions arise, such as : "Which will be the repercussions of deafness for the child and for the family?", "Are there possibilities for treatment, and where can help be found?" These are questions asked by the family, above all in this initial stage; which are followed by long term concerns: "Will she be able to speak, hear, communicate, study, have a job, a family, a social life?", "Will she be independent and autonomous?", "How will she be received by society?". These questions represent factors that may compromise the child's development and insertion into the world just like any other child.

In this study, an aggravating factor was detected, related to the manner in which the diagnosis was transmitted to one family: inadequately and insensitively. Moreover, it was verified that for the majority of the families, the alternatives and resources available for the treatment of deafness was omitted, and in a certain way, referrals were neglected.

Therefore, the parents of children with HI call for "freedom from misinformation", thus denominated by other authors ${ }^{(23)}$, because they no longer want to hear declarations such as: "there is no test that confirms hearing loss until 6-8 months of age", "don't worry about your concerns, children develop at different rates", "you don't have to do anything about this for six months or a year"; To the contrary, in the beginning there is an amount of need for knowledge and information that the family feels they need to know: implications relative to hearing loss; references and being referred to specialists necessary for the next stage in the process; knowledge about and understanding of the resources available ${ }^{(23-24)}$. Our results also confirm this.

Therefore, the nurse and other health professionals need to be alert to the feelings experienced by the family, and be prepared to inform them about the child's possibilities of development. It is imperative to stimulate confidence and security for the care of the child and for facing up to the difficulties ${ }^{(25)}$.

It is worth emphasizing that none of the children participating in the study underwent newborn hearing 
screening, although some maternity hospital have already become apt to perform this test at the time of the child's birth.

In Law No 12.303, of August 2, 2010, there is provision about this exam being mandatory in children born in all the hospitals and maternity clinics ${ }^{(26)}$. It is also known as the Newborn Hearing Screening (known in Brazil as the "teste da orelhinha"), in spite of the method being efficient for the early diagnosis of HI, there is a great challenge for the implementation of Newborn Hearing Screening throughout the country, considering that there are 3,111,502 newborns per year, and of these fewer than $10 \%$ are covered by Hearing Screening ${ }^{(27)}$.

We believe that it still the responsibility of nursing:

- to participate in prevention by means of strengthening immunization programs, considering that congenital and acquired infections may have been avoided and reduced, and consequently, also the sequelae caused by them;

- warn and guide parents right from the time of gestation about the use of teratogenic substances and ototoxic medications, and act in the implementation of hearing screening and monitoring services in newborns, preschool and schoolchildren;

- identify and trace situations of risk and indicated cases of HI with the Family Health Service teams at the Primary Health Services and in Hospital Institutions, and consequently, make reference and counter references between the levels of health care, with a view to ensuring the continuity of the necessary care and actions;

- work on actions of health education with the population about: care with hearing and how to avoid diseases; the importance of observing and identifying changes in hearing and behavior in the child; and other information about deafness;

- acquire knowledge and act as a multiplier of professional training, updating and technical support as regards auditory health, of various professionals in the different levels of health care.

\section{REFERENCES}

1. Caldas FF, Lemos AB, Tschiedel RS. O envolvimento do pai no processo de (re)habilitação auditiva de seu filho deficiente auditivo. Comun Ciênc Saúde. 2009; 20(1):17-28.

2. Canho PG, Neme CM, Yamada MO. [Male genitor emotional experiences in the rehabilitation process of a hearing impairment children]. Estud Psicol (Campinas). 2006; 23(3):261-9. Portuguese.

3. Demetrio SE. Deficiência auditiva e família. In: Bevilacqua MC, Moret AL, organizadoras. Deficiência auditiva: conversando com familiares e profissionais de saúde. São Paulo: Pulso Editorial; 2005. p. 235-51.

4. Incesulu A, Vural M, Erkam U. Children with cochlear implants: parental perspective. Otol Neurotol. 2003; 24(4):605-11.

\section{CONCLUSION}

Portraying the experience of the family when they discover the hearing impairment of a child pointed towards a broad horizon of action, both of the nursing professional and of other health professionals.

For the family the discovery of $\mathrm{HI}$ in their child, whether during gestation, at birth or in the first years of life, means the collapse of their future. This is because at this time, they contemplate the loss of the perfect and expected child, have their dreams shattered, expectations frustrated and face an uncertain future. We found that this state of mourning varies from family to family, depending on the process of acceptance, resources they have to face the situation, and the previous meaning attributed to hearing impairment. Frequently, the approach to the family of children with $\mathrm{HI}$ by the professionals involved has been inadequate, and diagnosis made late. This reality needs to be changed rapidly and it is necessary to implement Universal Hearing Screening in maternity hospitals as a national practice.

Researches that explore the diagnosis of $\mathrm{HI}$ in other age groups, such as adolescents, adults and the elderly need to be conducted in order to investigate how this experience occurs in these cases. In addition, one could investigate if and how other variables (gender, educational level, socioeconomic and cultural conditions), which were not specific objects of the evaluation in this study, interfere in this experience.

Finally, it is worth emphasizing the importance of conducting researches in this area, and thus contribute to the production of knowledge about the care of families of persons with hearing impairment

\section{ACKNOWLEDGEMENTS}

The authors thank the São Paulo State Research Support Foundation-FAPESP ("Fundação de Amparo à Pesquisa do Estado de São Paulo") and Personal Improvement Coordination for Higher Education- CAPES "Coordenação de Aperfeiçoamento de Pessoal de Nível Superior" for the financing which enabled this research to be conducted.
5. Yamanaka DA, Paiva e Silva RB, Zanolli ML, Paiva e Silva AB. [Cochlear implant in children: the parents' point of view]. Psic Teor Pesqui. 2010; 26(3):465-73. Portuguese.

6. Andrade MB, Vieira SS, Dupas G. Cerebral palsy: a study on family coping]. REME Rev Min Enferm. 2011; 15(1):86-96.

7. Boscolo CC, Santos TM. A deficiência auditiva e a família: sentimentos e expectativas de um grupo de pais de crianças com deficiência da audição. Distúrb Comun. 2005; 17(1):69-75.

8. Negrelli ME, Marcon SS. Família e criança surda. Ciênc Cuid Saúde. 2006; 5(1): 98-107.

9. Oliveira RG, Simionato MA, Negrelli ME, Marcon SS. A experiência de famílias no convívio com a criança surda. Acta Sci, Health Sci. 2004; 26(1):183-91.

10. Yamazaki AL, Masini EA. A surdez no contexto familiar: o 
olhar materno. Rev Saúde Pesqui. 2008; 1(2):125-8.

11. Gatto CI, Tochetto TM. Infantile hearing loss: implications and solutions]. Rev CEFAC. 2007; 9(1):110-5. Portuguese.

12. Isaac ML, Manfredi AK. Diagnóstico precoce da surdez na infância. Medicina (Ribeirão Preto). 2005; 38(3/4):235-44.

13. Margall SA, Honora M, Carlovich AL. A reabilitação do deficiente auditivo visando qualidade de vida e inclusão social. Mundo Saúde. 2006; 30(1):123-8.

14. Vieira AB, Macedo LR, Gonçalves DU. O diagnóstico da perda auditiva na infância. Pediatria (São Paulo). 2007; 29(1):43-9.

15. Pupo AC, Balieiro CR, Figueiredo RS. [Retrospective study of hearing impaired children and teenager: characterizing the etiologies and audiological aspects]. Rev CEFAC. 2008; 10(1):84-91. Portuguese.

16. Moeller MP. Early intervention and language development in children who are deaf and hard of hearing. Pediatrics. 2000; 106(3):E43-51.

17. Mussa C, Kioroglo OS, Bruscato WL, Iervolino SM, Campos CA. [The psychologist's action during a cochlear implant process: report of case]. Pediatr Mod. 2010; 46(1):26-30. Portuguese.

18. Charon JM. Symbolic interacionism: an introduction, an interpretation, an integration. 9th ed. New Jersey: Prentice Hall; 2007.

19. Strauss A, Corbin J. Pesquisa qualitativa: técnicas e procedimentos para o desenvolvimento da teoria fundamentada. 2 a ed. Porto Alegre: Artmed; 2008.

20. Mendes-Civitella MC. Desenvolvimento do comportamento auditivo. In: Bevilacqua MC, Moret AL, organizadoras. Deficiência auditiva: conversando com familiares e profissionais de saúde. São Paulo: Pulso Editorial; 2005. p. 55-61.
21. Colozza P, Anastasio AR. Screening, diagnosing and treating deafness - the knowledge and conduct of doctors serving in neonatology and/or pediatrics in a tertiary teaching hospital. Sao Paulo Med J. 2009; 127(2):61-5.

22. Victorio SC, Martinho AC, Santos RP. Avaliação da audição em crianças. In: Bevilacqua MC, Moret AL, organizadoras. Deficiência auditiva: conversando com familiares e profissionais de saúde. São Paulo: Pulso Editorial; 2005. p. 63-81.

23. DesGeorges, J. Family perceptions of early hearing, detection, and intervention systems: listening to and learning from families. Ment Retard Dev Disabil Res Rev. 2003; 9(2):89-93.

24. Yucel E, Derim D, Celik D. The needs of hearing impaired children's parents who attend to auditory verbal therapycounseling program. Int J Pediatr Otorhinolaryngol. 2008; 72(7):1097-111.

25. Lemes LC, Barbosa MA. Telling the mother that her newborn has a disability. Acta Paul Enferm. 2007; 20(4):441-5.

26. Brasil. Presidência da República. Lei n. 12303, de 2 de agosto de 2010. Dispõe sobre a obrigatoriedade de realização do exame denominado Emissões Otoacústicas Evocadas [Internet]. Diário Oficial da República Federativa do Brasil, Brasília (DF); 2010 Ago 3 [citado 2011 Jan 20]. Disponível em: <http:// www.planalto.gov.br/ccivil_03/_Ato2007-2010/2010/Lei/ L12303.htm

27. Alvarenga KF, Bevilacqua MC, Costa Filho OA, Martinez MA. Estado atual da saúde auditiva neonatal no Brasil: políticas públicas e evidências científicas. In: Bevilacqua MC, Martinez MA, Balen AS, Pupo AC, Reis AC, Frota S, organizadores. Saúde auditiva no Brasil: políticas, serviços e sistemas. São José dos Campos: Pulso Editorial; 2010. p. 97-118. 